\title{
Teaching Arabic in State Islamic University
}

\author{
Akmaliyah ${ }^{1}$, M. Rosyid Ridho ${ }^{2}$ \\ akmaliyah@uinsgd.ac.id \\ Faculty of Adab and Humanities, Universitas Islam Negeri Sunan Gunung Djati Bandung, \\ Indonesia
}

Received: 11 March 2020 Accepted: 11 May 2020

DOI: $10.24256 /$ ideas.v8i1.1256

\begin{abstract}
Serving as the language of al-Qur'an and everyday Islamic rituals both individually and in public congregation, Arabic is a necessary tool for all Muslims to complete their religious duties; therefore, Arabic subject is offered elsewhere starting from PAUD education to university level in our Muslim majority country. This study is going to discuss a specific aspect regarding the strategy of teaching Arabic in higher education. This specific aspect has already been our concern quite a while; it related to the 'upgrade' or the transformation of IAIN institution into UIN in which there are faculties with non-religious subjects and their students whose background are of non-or-minimum earlier religious education. In general, they were educated in public high school and had not enough study in Arabic; they were succinctly not familiar with its linguistic peculiarities. Qualitative in nature and with naturalistic approach, this study unveils the urgency of Arabic language proficiency for these students of non-religious faculties. It reveals as well the need for a shift in teaching strategies at UIN for students in non-religious faculties, in a systematic and proper way so that they may develop interest towards the study of Arabic language.
\end{abstract}

Keywords: arabic; teaching; Islamic Institute University

\section{Introduction}

Arabic is a necessary tool for all Muslims to complete their religious duties; it is the language of al-Qur'an, worship and religious books, so that in this greatest Muslim country in the world, Arabic subject is offered elsewhere here. Studying Arabic is definitely a necessity for all Muslims living in Indonesia.

Indeed, efforts to achieve the desired ability on both knowledge and skill in Arabic language are sought through the process of "learning" meaning attempts to obtain acquired skill or knowledge (Poerwadarminta, 1986: 108). Implied in it another process known as "teaching" by which a learner may get effective instruction to follow. According to an abridged dictionary of Indonesian language (KBBI, 2001: 17), teaching is a process and method which includes the following 
components: learning participants, instructors, learning material, teaching process, and evaluation.

Indonesian government stipulates Arabic language teaching and learning long since independence. Its materials are contained in the curriculum of formal and non-formal religious education institutions. It is taught starting from PAUD education to university level. This study is going to discuss a specific aspect regarding the strategy of teaching Arabic in higher education. This specific aspect has already been our concern quite a while; it related to the 'upgrade' or the transformation of IAIN institution into UIN in which there are faculties with non-religious subjects and their students whose background are of non-or-minimum earlier religious education.

The change in name itself has an impact on making the number of public enrollers more or less as expected increase. This university is flooded with throngs of students graduating from Public High School (SMU). Unfortunately, these students for the most part have not yet received enough Arabic language training in their previous study as they are now warmly welcomed entering this new environment where Arabic knowledge is required. To make understand all students (with their different background education) Arabic material learning so the teacher must use and try the developing methods. The methods are developed to make it easier to absorb Arabic knowledge for students of both religious and non-religious faculties, for example, it has been arranged first by UIN Malang that new students are required to stay in a full-facilitated dormitory or ma'had 'aly for at least one year before tuition class with the aim of learning Arabic (Syarifudin 2017, 262). In addition, the power of interest development is very important in designing a language teaching process (Maruddin,2018; Palangngan, 2019)

This study focuses on the teaching of Arabic in faculties with non-religious subjects and their students whose background are of non-or-minimum earlier religious education. It discusses the following issues: the first, the urgency of teaching Arabic at UIN for students in non-religious faculties; and the other, to explain the strategy of teaching Arabic at UIN to students in non-religious faculties.

\section{Method}

This research is a qualitative research with a naturalistic approach. The data that has been collected is analyzed using inferential descriptive method, that is, by way of projecting it in the context of an objective representation of the reality. The steps of the method then are first to describe, systematize the materials, then draw general conclusions about the object of the research. (Hadari Nawawi, 1985: 63).

Another method used here is the comparison. This method is used to compare various thoughts, information and field facts on issues related to the research title. This comparison is then used to find actuality, track relevance, alignment and then discover the possibilities regarding differences and similarities 
in theory and data. The mindset used is the relevance mindset that refers to a certain functional relationship within the area being researched. (Sutrisno Hadi, 1987: 3).

The data sources examined are obtained from primary and secondary data sources. Primary data sources are obtained from field materials in the form of observations, interviews and documentation of the analysis of Arabic teaching materials among students in the faculties of religion and non-religion at UIN Syarif Hidayatullah Jakarta, UIN Sunan Gunung Djati Bandung and UIN Sunan Ampel Surabaya and non-specified other PTKIN. Secondary data are obtained from literature studies or theories related to the research material being discussed.

Techniques in collecting qualitative data can be done by researchers after determining the focus of research. In this study the main data collected is in the form of observations, interviews and documentation related to Arabic teaching in the three PTKIN. Researchers collect data as well as other documents related to Arabic teaching materials, interview selected informants among lecturers and students, then assess the quality of the data, conduct data analysis, interpret and conclude it. The main and additional data will be collected through observation, interview, documentation and triangulation techniques.

After the data collected is analyzed through three paths as revealed by Miles and Huberman, namely reducing data, presenting data and drawing conclusions. Reducing data means summarizing, choosing the main things, focusing on the things that are most important, looking for themes and patterns. Presentation of data in qualitative research can be done in the form of a brief description, in the form of narrative texts. Displaying the data makes it easier to understand what is happening, to plan further work based on what is understood subsequently.

The initial conclusion drawn is forever considered temporary, meaning it will change if strong evidence is found that supports another one. Then comes the next stage of data collection. If the initial conclusions are supported by valid and consistent evidence, the conclusion presented might be considered credible.

\section{Results}

In formal education there is a curriculum that continues to develop from year to year. It includes Arabic language curriculum in Higher Education. The curriculum development that is at work is intended to improve teaching, student achievement or teaching outcomes to a better direction. Likewise, Arabic curriculum structure would change due to the transformation of IAIN institution to UIN and the increasing number of faculties. That would also have impact on teaching strategies, following the diversity of students' backgrounds.

The studies to be cited here have already mentioned the need for a new approach to learning Arabic in either religious or public tertiary institutions. Two of M. Ritonga's writings represent the tendency to harmonize Arabic teaching methods with the latest findings in modern technology. Ritonga's first article (2017), mentions the need to design Arabic Science teaching materials with the 
Whole Language approach (M. Ritonga, 2017). According to him, four Arabic-language skills maharah al-istima ', al-kalam maharah, al-qiro'ah maharah and al-kitabah maharah can be developed in general faculties by including materials that are relevant to the science of their students. In the Saintek faculty, for example, materials related to physics and technology were conveyed. The demand or catch is that the instructor must also understand and be in charge of the disciplines that the faculty students are in. In another article, Ritonga (2016) advocates the design of ICT-based Arabic learning models. Designed to find an ideal ICT-based Arabic learning model, this research assumes that the integration of various fields of study with ICT, including Arabic learning, is very important to be developed in this digital age (M. Ritonga, 2016).

In line with Ritonga, Dadang Firdaus (2013) recommends teaching Arabic to keep up with the times and make use of all modern facilities. According to his conclusion, the use of electronic-based learning media today really needs to be encouraged in learning Arabic. Modern technology through various forms, including internet-based learning media, television, visual-audio and others, needs to be utilized so that students no longer consider Arabic as "old school" material, but material that is always unique, interesting and modern (Dadang Firdaus, 2013). In the same spirit, Abd. Rozak et. All, (2018) advocates the use of Arabic lecture designs through Google Classroom (Abd. Rozak, 2018). According to the researcher, Google classroom is designed to facilitate lecturer interaction with students in cyberspace. This application opens broad opportunities for lecturers to share insights with students. The replacement is Google Apps for Education, Gmail, documents, and drives. Classes are prepared to make it easier for students to create and submit paperless assignments. So he was asked to prepare a drive folder for each task and other notes so that everything is organized

On the other hand, Faisal Hendra (2018) emphasized the role of student organizations in improving the quality of learning Arabic language skills. This is what other writers later called peer teaching. With an egalitarian family approach, a number of work programs can be carried out by student organizations, among others, reviving Arabic madding (wall newspaper), implementing Yaumul 'Arabi or Arabic day, Arabic typing courses and competitions, seminars on student level linguistics, journalism, calligraphy, debates, poetry, singing in Arabic, competitions, and competitions both locally, nationally and internationally and conducting Arabian festivals and carrying out Arabic teaching activities (Faisal Hendra, 2018).

Agung Setiyawan (2018) in his writing "Problems of Diversity of Student Education Backgrounds and Arabic Language Learning Program Policies," concluded that differences in the educational backgrounds of students in learning Arabic have become a source of problems in learning this language at the college level. These problems include: 1) There are gaps in learning, 2) Problems of ability adjustment, 3) Problems of slowing learning, 4) Problems of diverting and uniting the focus of learning, 5) Problems of feeling anxious, inadequate and afraid of 
learning, 6) The emergence lack of confidence, and 7) The emergence of laziness in learning. To overcome all these problems, several steps need to be done. These include: (1) Conducting class divisions in accordance with students' Arabic abilities; (2) Organizing a kind of additional class matriculation for students who still lack knowledge and ability about Arabic and (3) Implementing various learning models that vary according to learning needs, such as: contextual learning (Contextual Teaching Learning), role playing (Role Playing), participatory learning (Participative Teaching and Learning), complete learning (Mastery Learning), learning with modules (Modular Instruction) and inquiry learning. The problem solving offered by researchers is so comprehensive that it covers what students need to do themselves when they are lagging behind in their mastery of Arabic. Among others: (1) memorizing mufradât (Arabic vocabulary); (2) self-study (independent); (3) participating in group learning (halaqah) Arabic learning (peer teaching); (4) participating in language development UKM on campus; and (5) taking private lessons learning Arabic outside the campus.

To this extent the author has found the most up-to-date and complete discussion of Arabic teaching methods in religious and general faculties with students of different backgrounds. It's just because the locus of study is limited in one study program at a UIN campus in Yogyakarta, the author feels the need to complete it with materials covering three UIN campuses in two major cities besides Yogyakarta, namely Jakarta and Bandung. In other words, the research that will be carried out by this writer will be a continuation of the last research conducted by Agung Setiyawan.

Imam Suprayogo (2019), Professor of UIN Malik Ibrahim Malang, in a presentation delivered on August 26, 2015 entitled "Arabic Language and Islamic Studies in Higher Education," states that mastering Arabic should be required for all students studying at Islamic Higher Education without looked at the direction he chose. According to him, without the mastery of Arabic the results or outputs are good and the maximum is difficult to expect. The Arabic position is the instrument, device or entrance to the sciences that students will pursue in college. That is certainly if the core studies are religious sciences, what if the general sciences, does Arabic still need to be mastered? This question is enough to interfere with the academic community within PTKIN so that it encourages the writer to conduct research on teaching Arabic in the State Islamic University (UIN).

The philosophy behind the change of IAIN / STAIN into the State Islamic University (UIN) is idealism for integrating religious and general sciences. So that thus can be achieved hope to give birth to Muslim intellectuals who master the modern sciences while understanding the religious sciences well.

Because the transformation from IAIN to UIN requires a general study program, as stated by Prof. Hamdar Arraiyya (2019), then in UIN there are new faculties that were not initially cultivated and eventually demanded the presence of lecturers and office holders from outside the campus, for example the Faculty of Science and Technology, the Faculty of Psychology, then the Faculty of Social and 
Political Sciences. Some faculties that are traditionally owned by IAIN before undergoing the transformation must also change their name, for example from the Tarbiyah Faculty to the Tarbiyah and Teaching Faculty. The Adab Faculty became the Adab and Humanities Faculties, then the other Sharia Faculties became the Sharia and Law Faculties. This change implies scientific integration between religious and general sciences. However, as also confirmed by Prof. Hamdar Arraiyyah, this integration is not the same as the theory of Islamization of science as put forward by for example, Syed Muhammad Naquib al-Attas, Seyyed Hossein Nasr and Ismail Raji al-Faruqi. For the idea of Islamization of science see, dissertation of Imron Mustofa The Idea of Islamization of Science (Study of the Institute Methodology Framework for the Study of Islamic Thought and Civilization (Insists), Postgraduate of Sunan Ampel State Islamic University, Surabaya 2018.

Apparently, the philosophy underlying the Islamization of science is epistemology of science as an entity that is inseparable from value. Al-Attas sees that modern science is too intellectual and denies the participation of values. Nasr rejects the nature of modern science which erases the traces of God in nature, while al-Faruqi considers the dichotomy of science and values as malaise in the education system. The integration of religion and general science in question seems to be the adoption of a model like that of Imam Suprayogo (2011) as the "Tree of Science" model. The basic idea is the similarity of functions between science and religion as a means of understanding nature and life. This idea was formulated into three levels. First, al-Qur'an and sunnah are placed as sources of inspiration, basic concepts that demand actualization and are at the same time a source of knowledge (Imam Suprayogo, 2005). Second, the curriculum is elaborated through the principle of tarbiyat ûlû al-albāb (intellectual candidate education). This principle emphasizes that spirituality, noble character, the breadth of knowledge and the maturity of professionalism as a vision and mission are carried out through collaboration between remembrance, thought and good deeds. The third step is the implementation, namely: the formation of climate and campus culture. The assumption is that ownership of knowledge must appear in the actions of the good owner; scientific professionalism and Islamic culture must go in harmony (Imam Suprayogo, 2008).

\section{Discussion}

Learning Arabic at the State Islamic University will certainly be different from pesantren. Different environments will produce different quality of learning. Learning Arabic in pesantren is carried out intensively every day (Wekke, 2015: 289). In boarding schools, students must live in one boarding school environment, so that Arabic is widely used in activities in the classroom and outside the classroom. The learning of Arabic in tertiary institutions is very limited, students are not required to live in one environment, then there is not much use of Arabic either in KBM (teaching and learning activities) or non-KBM. With the intensity of 
learning that is lower than pesantren, logically the quality of Arabic learning at the State Islamic University Higher Education should be lower. Therefore, researchers try to examine what are the specific obstacles in learning Arabic at the State Islamic University and then find solutions to overcome these problems.

According to Muhbib Abdul Wahab (2008: 105-106) in his paper presented at the BEMJ PBA FITK UIN Jakarta Day Seminar, May 29, 2006, there are four educational orientations in learning Arabic, namely

1. Religious Orientation, namely learning Arabic which aims to understand Islamic religious texts.

2. Academic Orientation, namely learning Arabic which aims to practice academic skills in Arabic (listening, speaking, reading, and writing). In this type, Arabic is used as a field of special science studies.

3. Professional / Practical and Pragmatic Orientation, namely Arabic learning that aims to meet professional and practical needs such as continuing studies in the Middle East, TKI, tourists, ambassadors, cooperation between countries, etc.

4. Ideological and Economical Orientation, namely learning Arabic which aims to use and understand Arabic for certain interests, such as orientalism and capitalism.

In learning Arabic at the State Islamic University, the orientation of learning will differ according to the department. For majors such as Arabic Language Education or Arabic Literature, the orientation of the focus is number two and three. For majors such as the Science of the Qur'an, the orientation is number one. For general majors, the orientation is number two, which is only to practice the language skills, without the need to understand the deep elements in Arabic.

There are two terms in Arabic for "teaching". The first is ta 'iim, which is the activity of providing knowledge by using media in learning. The second is tadris, namely the interaction between students and their environment, which is then associated with learning and student responses to it (Salamah, 2003: 15-16). If synthesized, then learning in theory Arabic is an activity providing knowledge through a medium to observe students' responses as well as to learning and the environment.

In order to keep Arabic in demand by students in religious and non-religious faculties, and with this specialization, students can master the Arabic language properly and correctly, both by students in religious and non-religious faculties. So that it can achieve the hope of the establishment of UIN, which gave birth to Muslim scholars who understand the language of the Qur'an, namely Arabic, properly. The mastery of Arabic and understanding the Qur'an properly and correctly is a capital to be a perfect scholar in the midst of society, namely mastering general knowledge and mastering the science of religion.

That the change of IAIN into UIN is expected not to change the character of Islamic Higher Education institutions, which deal with religion. There is a concern in the minister of education regarding the change of several IAINs into UIN, although, the Ministry of Education and Culture (Kemendikbud) does not dispute 
the desire of a number of State Islamic Religion Institutions (IAIN) to change their status to State Islamic University (UIN). However, according to him, what happened so far, there was a change in the essence of science when IAIN became UIN. This is what he thinks should not happen. The concern of this minister of national education can be answered by staying awake in the core sciences, Arabic material, for example, being taught at UIN.

\section{Conclusion}

Teaching Arabic is still very urgent taught at UIN for students in non-religious faculties. Considering the educational background and students' interest in non-religious faculties, it is necessary to have an Arabic teaching strategy at UIN for students in non-religious faculties, so that students' concerns and interests in Arabic remain as expected by the institution.

\section{References}

Abdul Wahab, Muhbib, (2008). Epistemologi dan Metodologi Pembelajaran Bahasa Arab. Jakarta: UIN Jakarta Press.

Arraiyyah, H.M. Hamdar, "Model Integrasi Keilmuan di Universitas Islam Negeri" https://balitbangdiklat.kemenag.go.id/berita/model-integrasi-keilmuan-diuniversitas-islam-negeri, accessed 19 October 2019

Departemen Pendidikan Nasional. (2008). Kamus Besar Bahasa Indonesia. Jakarta: Balai Pustaka.

Departemen Pendidikan Nasional. (2001). Kamus Besar Bahasa Indonesia. Jakarta: Balai Pustaka. 3rd edition.

Firdaus, Dadang. (2013). "Istikhdam wasail al-ta'lim al-Iliktruni" Journal of English and Arabic Language Teaching (JEALT) vol. 4, no. 2

Hadi, Sutrisno. (1987). Metodologi Research I. Yogyakarta : Fakultas Psikologi Universitas Gajah Mada.

Hadi, Sutrisno. (2004). Metodologi Research. Yogyakarta: Andi Press.

Hendra, Faisal (2018). Peran Organisasi Mahasiswa Dalam Meningkatkan Mutu Pembelajaran Keterampilan Berbahasa Arab. Arabiyat : Jurnal Pendidikan Bahasa Arab dan Kebahasaaraban Vol. 5 No. 1, Juni, 103-120

Masruddin, M. (2018) THE STUDENTS INTEREST TOWARDS THE USE OF NATURAL APPROACH IN TEACHING SPEAKING. IDEAS: Journal on English Language Teaching and Learning, Linguistics and Literature, 1(2). doi:https://doi.org/10.24256/ideas.v1i2.169

Nawawi, Hadari. (1985). Metode Penelitian Bidang Sosial. Yogyakarta : Gajah Mada University.

Nizar, Samsul. (2007). Sejarah Pendidikan Islam Menelusuri Jejak Sejarah Pendidikan Era Rasulullah Sampai Indonesia. Jakarta: Kencana Prenada Media Group.

Mustofa, Imron (2018) Gagasan Islamisasi Ilmu (Studi Tentang Kerangka Metodologi Institute For The Study Of Islamic Thought And Civilization (Insists)), Pascasarjana Universitas Islam Negeri Sunan Ampel Surabaya 
Palangngan, S., \& Mulyaningsih, E. (2019). Students' Interest in Learning English through Belajar Bahasa Inggris With Aco Application. IDEAS: Journal on English Language Teaching and Learning, Linguistics and Literature, 7(2). doi:https://doi.org/10.24256/ideas.v7i2.1025

Poerwadarminta, W.J.S. (1986). Kamus Umum Bahasa Indonesia. Jakarta: Balai Pustaka

Rinaldo.

In

https://www.liputan6.com/news/read/647118/mendikbud-iain-berubah-i adi-uin-siapa-yang-urus-agama accessed 19 October 2019

Ritonga, M. (2017). Desain Bahan Ajar Bahasa Arab Sains Dengan Pendekatan Whole Language. Edukasi: Jurnal Pendidikan Islam, 5(2), 001 - 024. et. All (2016). Pembelajaran Bahasa Arab Berbasis Teknologi Informasi dan Komunikasi di kota Padang. Arabiyat : Jurnal Pendidikan Bahasa Arab dan Kebahasaaraban, Volume 3 Number 1

Rozak, Abd. et. All (2018), "Desain Perkuliahan Bahasa Arab melalui Google Classroom" Arabiyat: Jurnal Pendidikan Bahasa Arab dan Kebahasaaraban Vol. 5 No. 1, 83-102

Salāmah, `Abd Al-Ḥāfiz Muhammad. (2003). Asasiyyāt fi Taṣmīm al-Tadrīs. Riyāḍ: Dār Al-Khārijī.

Setiyawan, Agung (2018), "Problematika Keragaman Latar Belakang Pendidikan Mahasiswa dan Kebijakan Program Pembelajaran Bahasa Arab" Arabiyat : Jurnal Pendidikan Bahasa Arab dan Kebahasaaraban Vol. 5 No. 2, Desember, 195-213

Suprayogo, Imam. Hubungan antara Perguruan Tinggi dan Pesantren (Malang: UIN-Malang Press, 2011), 45.

Suprayogo, Imam. (2006). Paradigma Pengembangan Keilmuan Islam Perspektif UIN Malang. Malang: UIN-Malang Press. 49-55, 100-101. . (2006). Paradigma Pengembangan. 57, 165-167

Syarifudin, Achmad. (2017). Analisis Kebutuhan Materi Ajar Berbicara Bahasa Arab Berbasis Pendekatan Komunikatif bagi Pembelajar Non-Bahasa Arab. Intizar vol. 23, no. 02, 262.

Wekke, Ismail Suardi. (2015). Arabic Teaching and Learning: A Model from Indonesian Muslim Minority. Procedia: Social and Behavioral Sciences. 286-290. 